\title{
Pengaruh Cognitif Behavior Therapy dalam Memperkuat Empati pada Remaja dengan Perilaku Agresif
}

\author{
Latifah Nur Ahyani dan Dwi Astuti \\ Fakultas Psikologi Universitas Muria Kudus Gondangmanis, Bae, Kudus, Jawa Tengah \\ psikologi@umk.ac.id
}

\begin{abstract}
Aggression committed by juveniles with school background due to poorly developed conscience in teenagers , lack of impulse control , lack of sensitivity to moral values . One of the factors that can lead to aggressive behavior is aggressive models. Through CBT ( cognitive Behavior Therapy ) presented a model that negates the emergence of aggressive behavior and emphasize empathy so that individuals can replicate the model, individuals can capture the inspiration of the behavior which negates the aggression and may be granted when it appears strengthening empathy. The purpose of this study is to empirically examine the effect of CBT (cognitive behavior therapy) to strengthen empathy in adolescents with aggressive behavior. Results of data analysis showed that there are significant differences in the level of aggression between $99 \%$ rate before getting treatment CBT ( cognitive Behavior Therapy ) after getting treatment with CBT . After getting the CBT treatment aggressiveness level lower than before getting CBT treatment . Different coefficient of 4.093 with a p t of $0.001(p<0,05)$. There is a significant difference in the level of empathy between the $99 \%$ level before getting treatment after getting CBT with CBT treatment . After getting treatment CBT empathy levels higher than before getting the CBT treatment . Different coefficient of -3.916 with a $\mathrm{p} t$ of $0.002(\mathrm{p}<0,05)$. The magnitude of the effect of CBT on aggressive behavior seen in the effective contribution of $23.7 \%$. The magnitude of the effect of CBT on empathy appears on the effective contribution of $30.8 \%$. Effective contribution is large enough to be considered significant .
\end{abstract}

Keywords : Aggressive Behavior, CBT ( cognitive Behavior Therapy ), Empathy

\begin{abstract}
ABSTRAK
Agresifitas yang dilakukan oleh remaja dengan latar belakang sekolah disebabkan adanya nurani yang kurang berkembang pada remaja, kurangnya kontrol terhadap impuls, kurangnya sensitivitas terhadap nilai moral. Salah satu faktoryang dapat menimbulkan perilaku agresif adalah model agresif. Melalui CBT (Cognitif Behavior Therapi) dihadirkan model yang meniadakan perilaku agresif dan menekankan munculnya empati sehingga individu dapat meniru model, individu dapat menangkap inspirasi mengenai perilaku yang meniadakan agresi dan dapat diberikan penguatan ketika muncul empati. Tujuan dari penelitian ini adalah untuk menguji secara empiris pengaruh CBT (cognitif behavior therapi) dalam memperkuat empati pada remaja dengan perilaku agresif. Hasil analisis data menunjukkan bahwa ada perbedaan yang sangat signifikan pada taraf 99\% tingkat agresifitas antara sebelum mendapatkan perlakuan CBT (Cognitif Behavior Therapy) dengan sesudah
\end{abstract}


mendapatkan perlakuan CBT. Setelah mendapatkan perlakuan CBT tingkat agresifitas lebih rendah dibandingkan sebelum mendapatkan perlakuan CBT. Besarnya koefisien beda dengan t sebesar 4,093 dengan $p$ sebesar $0,001(p<0,05)$. Ada perbedaan yang sangat signifikan pada taraf $99 \%$ tingkat empati antara sebelum mendapatkan perlakuan CBT dengan sesudah mendapatkan perlakuan CBT. Setelah mendapatkan perlakuan CBT tingkat empati lebih tinggi dibandingkan sebelum mendapatkan perlakuan CBT. Besarnya koefisien beda dengan t sebesar -3,916 dengan p sebesar 0,002 ( $<<0,05)$. Besarnya pengaruh CBT terhadap perilaku agresif tampak pada sumbangan efektif yaitu sebesar 23,7\%. Besarnya pengaruh CBT terhadap empati tampak pada sumbangan efektif yaitu sebesar 30,8\%. Sumbangan efektif yang cukup besar ini penting untuk diperhatikan.

Kata kunci : CBT (Cognitif Behavior Therapy), Empati, Perilaku Agresif.

\section{PENDAHULUAN}

Aksi kekerasan dapat terjadi di mana saja, seperti di jalan-jalan, di sekolah, di komplekskompleks perumahan, bahkan di pedesaan. Aksi tersebut dapat berupa kekerasan verbal (mencaci maki) maupun kekerasan fisik (memukul, meninju, dll). Pada kalangan remaja aksi yang biasa dikenal sebagai tawuran pelajar/masal merupakan hal yang sudah terlalu sering kita saksikan, bahkan cenderung dianggap biasa. Pelaku-pelaku tindakan aksi ini bahkan sudah mulai dilakukan oleh siswa-siswa di tingkat SLTP/SMP. Hal ini sangatlah memprihatinkan bagi kita semua Aksi-aksi kekerasan yang sering dilakukan remaja sebenarnya adalah prilaku agresi dari diri individu atau kelompok. Agresif menurut Murry (Halll dan Lindzey,1993) didefinisiakan sebagi suatu cara untuk melawan dengan sangat kuat, berkelahi, melukai, menyerang, membunuh, atau menghukum orang lain. Singkatnya agresi adalah tindakan yang dimaksudkan untuk melukai orang lain atau merusak milik orang lain.

Agresifitas yang dilakukan oleh anak-anak dengan latar belakang sekolah disebabkan adanya nurani yang kurang berkembang pada anak, kurangnya kontrol terhadap impuls dan kurangnya sensitivitas terhadap nilai moral. Salah satu faktor utama adalah pengaruh lingkungan yang tidak menunjang terbentuknya nilai moral yang positif. Sumber-sumber nilai moral yang diperoleh anak dari lingkungan adalah televisi, film, suratkabar, sekolah, teman sebaya dan institusi kemasyarakatan lainnya. Transmisimoral dimulai dari keluarga khususnya orang tua sebelum anak beranjak ke luar rumah.

Bermula dari masa anak-anak terus berkembang menjadi seorang remaja, yang tidak banyak bergantung lagi pada orangtua, mereka akan lebih mengandalkan diri sendiri dalam memenuhi kebutuhan dan menyelesaikan kesulitan yang dihadapi, lebih senang berkumpul dengan sebayanya dan mencoba hal-hal baru bersama-sama, yang selama ini mereka dianggap anak-anak, hanya mereka lihat dan dengar dari orang dewasa atau media lainnya. Karena awal dari banyaknya perilaku anak seringkali terinspirasi oleh orangtuanya dan pengaruhpengaruh lain disekitarnya dalam kehidupannya.

Naluri yang lemah, kontrol diri yang rapuh, kepekaan moral yang kurang dan keyakinan yang salah membuat anak-anak mengalami hambatan. Anak-anak sering menjadi korban dan pelaku berbagai bentuk tindak kekerasan dan bentuk 
tindak kriminal. Terjadi peningkatan jumlah anak yang melakukan bunuh diri akibat tidak adanya kepekaan, kepedulian maupun perlindungan terhadap anak-anak yang berada dalam kondisi berisiko.

Berbagai bentuk kekerasan seperti pemalakan (bullying), tawuran, pencurian, dan pencabulan banyak dilakukan oleh anak-anak dari berbagai tingkat pendidikan, usia, dan hampir terjadi di daerah perkotaan maupun pedesaan. Menurut Olweus (Krahe, 2001), anak-anak muda yang agresif dan melakukan tindakan bullying terhadap anak lain di sekolah menghadapi risiko terlibat dalam perilaku bermasalah lain di masa mendatang, seperti kriminalitas, dan penyalahgunaan alkohol.

Berdasarkan hasil penelitian yang dilakukan oleh Õzkan \& Cifci (2009) yang menyatakan bahwa ada korelasi positif antara perilaku bullying dengan rendahnya kemampuan empati, meningkatnya kemampuan empati akan menurunkan perilaku bullying. Lebih lanjut, anak yang melakukan kekerasan atau agresi adalah anak yang memiliki kontrol diri yang rendah, kemampuan perspective taking yang rendah, empati pada orang lain yang tidak berkembang. Bullying diduga disebabkan oleh minimnya pemahaman mereka terhadap nilai diri yang positif oleh karenanya sikap saling menghargai, menolong, berempati, jujur, lemah lembut dan sebagainya tidak jarang hilang dari pribadi anak.

Gamayanti (2003) menyatakan perilaku asosial yang dilakukan individu mengindikasikan bahwa individu tidak mampu mengontrol dirinya sendiri, kurang peka terhadap orang lain, kurang peka pada situasi dan lingkungan, serta tidak memiliki rasa aman.

Praktik kekerasan itu sendiri disebabkan oleh banyak faktor, Brotoseno menyatakan bahwa salah satu faktor yang menyebabkan individu terlibat dalam kekerasan adalah rendahnya empati, tidak memiliki toleransi dan tidak mampu memahami perasaan orang yang dianiaya (Brotoseno, 2008). Lebih lanjut, individu yang melakukan kekerasan atau agresi adalah individu yang memiliki kontrol diri yang rendah, kemampuan perspective taking yang rendah, empati pada orang lain yang tidak berkembang.

Borba (2001) menyatakan sejumlah faktor sosial kritis yang membentuk karakter bermoral secara perlahan mulai runtuh, yaitu pengawasan orangtua, teladan perilaku bermoral, pendidikan spiritual dan agama, hubungan akrab dengan orang dewasa, sekolah khusus, norma-norma nasional yang jelas, dukungan masyarakat, stabilitas, dan pola asuh yang benar.

Untuk menyikapi kondisi tersebut diperlukan perubahan dan kerja sama kita semua, terutama para orangtua dan pendidik, karena menghindar dari serbuan pengaruh globalisasi tidaklah mungkin, yang bisa kita lakukan adalah siap menghadapinya. Melalui CBT (Cognitif Behavior Therapi) individu dapat meniru model, individu dapat menangkap inspirasi mengenai perilaku moral, dapat diberikan penguatan sehingga setahap demi setahap individu dapat meningkatkan kontrol diri, dapat memperkuat empati dan dapat menurunkan perilaku agresif pada remaja. Tujuan dari penelitian ini adalah untuk menguji secara empiris pengaruh CBT(cognitif behavior therapi) dalam memperkuat empati pada remaja dengan perilaku agresif.

\section{METODE PENELITIAN}

Rancangan penelitian ini menggunakan model The Untreated Control Group Design with Pretest and Posttest (Cook \& Campbell, 1979). Desain ini menggunakan dua kelompok yang diamati yang terdiri dari satu kelompok eksperimen dan satu kelompok kontrol. Pengukuran dilakukan dua kali yaitu sebelum diberikan perlakuan (pre-test) dan sesudah diberikan perlakuan (post-test). 


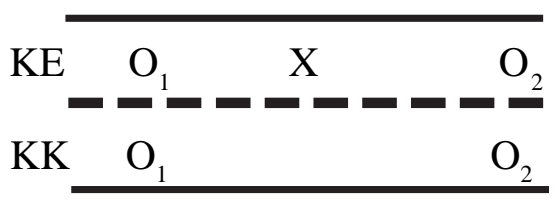

Gambar1. Desain Rancangan Eksperimen

Keterangan :

KE : Kelompok Eksperimen

KK : Kelompok Kontrol

$\mathrm{O}_{1}$ : Pre-test perilaku agresif, empati

$\mathrm{O}_{2}$ : Post-test perilaku agresif, empati

$\mathrm{X}$ :CBT

Proses eksperimen dalam penelitian ini terdiri dari satu perlakuan yaitu CBT. Pada tahap awal, siswa diminta untuk mempersiapkan diri mendengarkan instruksi yang diberikan oleh eksperimenter dengan tenang. Selanjutnya siswa akan diminta menyaksikan suatu film. Pada tahap evaluasi, siswa akan mendapatkan beberapa pertanyaan sebagai evaluasi untuk mengetahui pemahaman siswa tentang isi film. Pada tahap berikutnya, siswa diminta untuk bermain peran sesuai dengan tema yang telah disediakan. Siswa diajak untuk menyimpulkan nilai moral yang terkandung dalam peran tersebut. Proses ini akan berlangsung dalam waktu 180 menit.

Penelitian ini juga menggunakan kelompok kontrol yaitu kelompok yang tidak mendapat perlakuan tertentu dari proses penelitian ini. Siswa dalam kelompok kontrol tetap belajar seperti biasa sesuai dengan jadwal kurikulum yang sudah ditetapkan oleh sekolahnya. Kelompok ini dipergunakan untuk mengetahui bagaimana perkembangan empati dan perilaku agresif yang tidak mendapatkan perlakuan secara khusus.

Instrumen Penelitian terdiri dari :

a. Skala Perilaku agresif

Skala ini disusun untuk mengukur tingkat perilaku agresif. Skala perilaku agresif disusun berdasarkan empat aspek perilaku agresif menurut Johnson \& Medinnus (Farida, 2007) yaitu menyerang dengan atau pada fisik, menyerang pada benda atau objek, menyerang secara verbal atau simbolik, pelanggaran terhadap hak milik orang lain atau menyerang daerah orang lain.

b. Skala Empati

Skala empati merupakan modifikasi dari skala empati dari Zoll dan Enz (2012). Skala empati dari Zoll dan Enz (2012) meliputi 28 item dan lima poin bentuk respon ("Saya sangat setuju” - "Saya sangat tidak setuju”). Skala empati ini menangani empati kognitif dan afektif dan dikembangkan menggunakan item baru yang juga item dari instrument untuk penilaian empati yang telah ada; dari Bryan (1982) Index Penilaian untuk anak-anak dan remaja yang mana versi seorang anak dan remaja, dari Mehrabian dan Epstein (1972) menilai empati emosional pada orang dewasa, item dari Leibetseder E-skala (2001), item dari sebuah adaptasi milik davis Index Reaktifitas Antar Pribadi (IRI) untuk anakanak oleh Garton dan Gringart (2005). Item yang dipilih nampak sesuai untuk menunjukkan aspek teoritikal dari empati: empati kognitif dan afektif. Item-item yang dikembangkan oleh penulis dikembangkan untuk menambah kelompok item. Sebagai alasan untuk validasi lebih lanjut, keenam item dari Eisenberg et al. Skala simpati laporan anak $(1996,1998)$ juga disertakan.

c. Modul CBT

Perlakuan yang diberikan dalam penelitian ini adalah CBT (Cognitif Behavior Therapi). Sebuah modul CBT dirancang bagi remaja dengan perilaku agresif dengan tujuan untuk meningkatkan empati, nurani dan kontrol diri.

Modul CBT di susun dengan mengajak remaja berpikir dan berperilaku yang empatik, sesuai nurani dan memiliki kontrol diri. Nilai empati, nurani dan kontrol diri terkandung dalam setiap tema, penelitian ini dilakukan dalam 6 kali 
Tabel 1: Prosedur Pelaksanaan CBT

\begin{tabular}{|c|c|c|c|}
\hline SESI & TEMA & AGENDA KEGIATAN & TUJUAN \\
\hline I & Pengantar & $\begin{array}{l}\text { Membangun hubungan } \\
\text { terapi } \\
\text { Pengenalan CBT } \\
\text { Testimoni } \\
\text { Memaparkan } \\
\text { menceritakan karakter } \\
\text { diri, kelebihan dan } \\
\text { kelemahan pada orang } \\
\text { lain dengan lugas. }\end{array}$ & $\begin{array}{l}\text { a. Mempersiapkan peserta untuk mengikuti proses } \\
\text { terapi } \\
\text { b. Membuat norma-norma yang harus disepakati } \\
\text { bersama } \\
\text { c. Menumbuhkan motivasi peserta untuk dapat } \\
\text { mengikuti keseluruhan proses terapi agar dapat } \\
\text { memperoleh manfaat dari proses terapi secara } \\
\text { maksimal } \\
\text { d. Mengenal diri sendiri lebuh jauh, Memahami } \\
\text { dan mau menerima kondisi sendiri, Sharing } \\
\text { dengan group }\end{array}$ \\
\hline II & $\begin{array}{l}\text { Nurani } \\
\text { Materi } \\
\text { CBT }\end{array}$ & $\begin{array}{l}\text { Mendiskripsikan karakter } \\
\text { Video Clip A-B-Cs: } \\
\text { Re-learning A } \\
\text { Pemberian materi CBT } \\
\text { Role play } \\
\text { Tebak Ekspresi }\end{array}$ & $\begin{array}{l}\text { a. Peserta memahami orang terdekat, keluarga, } \\
\text { b. Peserta mampu menganalisa karakter, } \\
\text { mamahami karakter, cara berfikir, sudut } \\
\text { pandang oranglain. } \\
\text { c. Peserta mengobservasi tayangan video clip. } \\
\text { Mampu menganalisa ekspresi wajah. Mampu } \\
\text { menginternalisasi, memahami suasana video } \\
\text { clip. Mampu mendiskripsikan apa yang } \\
\text { dirasakan dalam video clip. Mengasah } \\
\text { kemampuan mendengarkan, observasi, } \\
\text { pengamatan pada subjek. } \\
\text { d. Mengetahui secara umum Cognitif Behavior } \\
\text { Therapy, Mengetahui manfaat CBT } \\
\text { e. Memahami apa yang dirasakan orang lain } \\
\text { melalui ekspresi wajah dan bahasa non verbal. } \\
\text { Melatih peserta untuk lebih cermat dan peka }\end{array}$ \\
\hline III & $\begin{array}{l}\text { Pengenalan } \\
\text { empati, } \\
\text { moral }\end{array}$ & $\begin{array}{l}\text { Role play video clip } \\
\text { (dimensi kognitif, dimensi } \\
\text { emosional, dimensi } \\
\text { moral) Role play sharing } \\
\text { pengal aman mengesankan }\end{array}$ & $\begin{array}{l}\text { a. Peserta mengobservasi tayangan video clip } \\
\text { b. Mampu menganalisa ekspresi wajah , } \\
\text { menginternalisasi, memahami suasana video } \\
\text { clip, mendiskripsikan apa yang dirasakan dalam } \\
\text { video clip, mengasah kemampuan } \\
\text { mendengarkan, observasi, pengamatan pada } \\
\text { subjek. Mengasah kemampuan persepsi peserta }\end{array}$ \\
\hline IV & $\begin{array}{l}\text { Materi } \\
\text { empati } \\
\text { perilaku, } \\
\text { kontrol diri }\end{array}$ & $\begin{array}{lr}\text { Role Play I } & \text { Sharing } \\
\text { pengal aman } & \text { secara } \\
\text { berkelompok. } & \end{array}$ & $\begin{array}{l}\text { Peserta mengetahui pengaruh empati dengan } \\
\text { perilaku yang positif dan yang negative, } \\
\text { Melatih peserta untuk menembangkan empati } \\
\text { sebagai sarana munculnya perilaku yang positif }\end{array}$ \\
\hline V & $\begin{array}{l}\text { Empati, } \\
\text { nurani, } \\
\text { kontrol diri }\end{array}$ & $\begin{array}{l}\text { Role play I } \\
\text { Sosiodrama }\end{array}$ & $\begin{array}{l}\text { Bisa merasakan perasaan orang lain, dapat } \\
\text { berfikir dengan sudut pandang orang lain, dapat } \\
\text { menerima saran orang lain, latihan empati. }\end{array}$ \\
\hline VI & Evaluasi & $\begin{array}{l}\text { Sharing pelaksanaan } \\
\text { terapi }\end{array}$ & $\begin{array}{l}\text { Pengalaman sebelum saat dan sesudah terapi, } \\
\text { manfaat terapi bagi diri sendiri, apa yang } \\
\text { didapat setelah terapi. }\end{array}$ \\
\hline
\end{tabular}


pertemuan sehingga dibutuhkan 6 tema berbeda yang mengandung nilai empati, nurani dan kontrol diri. Waktu yang dibutuhkan dalam satu kali pertemuan adalah 180 menit.

Proses eksperimen di kelas disusun dengan tujuan untuk mempermudah dan memberikan pedoman bagi eksperimenter dalam menyampaikan materi. Berdasarkan tujuan tersebut maka kegiatan di kelas disusun dengan urutan sebagai berikut :

1. Kegiatan awal, siswa diminta untuk duduk tenang dan diajak untuk menyimak tema yang akan disampaikan oleh eksperimenter.

2. Pelajaran inti, pada sesi ini eksperimenter menyampaikan tema yang didalamnya terkandung nilai-nilai moral.

3. Evaluasi, pada sesi ini eksperimenter memberikan beberapa pertanyaan untuk mengetahui pemahaman siswa tentang isi tema

Kegiatan penutup, pada sesi ini siswa diajak untuk menyimpulkan nilai empati, nurani dan kontrol diri yang terkandung dalam tematema tersebut.

Untuk menguji hipotesis yang diajukan, data-data yang terkumpul akan dianalisis secara statistik melalui uji beda (t). Dalam penelitian ini uji beda $(\mathrm{t})$ digunakan untuk mengetahui apakah ada perbedaaan tingkat perilaku agresif antara sebelum mendapatkan perlakuan melalui metode CBT dengan sesudah mendapatkan perlakuan dengan metode CBT. Selain itu juga untuk mengetahui apakah ada perbedaaan tingkat empati antara sebelum mendapatkan perlakuan melalui metode CBT dengan sesudah mendapatkan perlakuan dengan metode CBT.

\section{HASIL DAN PEMBAHASAN}

Sebelum analisis dilakukan, terlebih dahulu dilakukanuji asumsi yang meliputi : uji normalitas sebaran dan uji homogenitas. Uji normalitas dalam penelitian ini menggunakan formulasi onesample Kolmogorov-Smirnov test. Hasil uji normalitas pada variabel perilaku agresif menunjukkan bahwa sebaran data kedua kelompok subjek adalah normal dengan $\mathrm{p}$ sebesar 0,936 $\mathrm{p}>0,05$ untuk data pre-test dan p sebesar $0,784 \mathrm{p}>0,05$ untuk data post-test pada kelompok eksperimen, p sebesar 0,996 p $>0,05$ untuk data pre-test dan p sebesar 0,757 $\mathrm{p}>0,05$ untuk data post-test pada kelompok kontrol, sehingga pengujian asumsi kemudian dilanjutkan pada uji homogenitas. Uji homogenitas menunjukkan $\mathrm{F}$ sebesar 0,664 dengan p sebesar 0,422 ( $p>0,05)$. Berdasarkan hasil tersebut maka dapat dinyatakan bahwa varian variabel terikat adalah homogen.

Sedangkan hasil uji normalitas pada variabel empati menunjukkan bahwa sebaran data kedua kelompok subjek adalah normal dengan p sebesar 0,861 p > 0,05 untuk data pre-test dan $\mathrm{p}$ sebesar $0,497 \mathrm{p}>0,05$ untuk data post-test pada kelompok eksperimen, $\mathrm{p}$ sebesar 0,883 $\mathrm{p}>0,05$ untuk data pre-test dan p sebesar 0,805 p >0,05 untuk data post-test pada kelompok kontrol, sehingga pengujian asumsi kemudian dilanjutkan pada uji homogenitas. Uji homogenitas menunjukkan $\mathrm{F}$ sebesar 3,763 dengan p sebesar 0,063 (p > $0,05)$. Berdasarkan hasil tersebut maka dapat dinyatakan bahwa varian variabel terikat adalah homogen.

Uji hipotesis dilakukan dengan menggunakan analisis uji beda (t). Berdasarkan hasil analisis data diperoleh besarnya koefisien beda dengan $t$ sebesar 4,093 dengan p sebesar $0,001(p<0,05)$ yang berarti sangat signifikan. Hasil penelitian yang diperoleh menunjukkan bahwa ada perbedaan yang sangat signifikan pada taraf 99\% tingkat agresifitas antara sebelum mendapatkan perlakuan CBT (Cognitif Behavior Therapy) dengan sesudah mendapatkan perlakuan CBT. Setelah mendapatkan perlakuan CBT tingkat agresifitas lebih rendah dibandingkan sebelum mendapatkan perlakuan CBT. Berdasarkan nilai partial eta squared ( $c^{2}$ ) diketahui besarnya sumbangan 
CBT terhadap perilaku agresif pada remaja adalah $23,7 \%$.

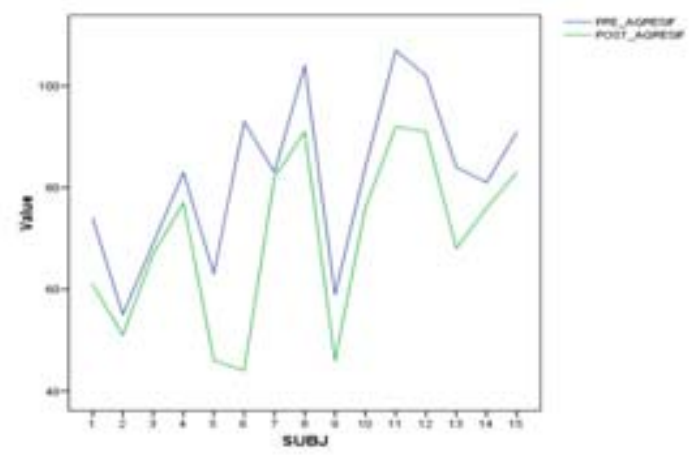

Gambar 2. Grafik Skor Pretest dan Posttest

Selain itu, berdasarkan hasil analisis data juga diperoleh besarnya koefisien beda pada variabel empati dengan t sebesar -3,916 dengan p sebesar 0,002 $(\mathrm{p}<0,05)$ yang berarti sangat signifikan. Hasil penelitian yang diperoleh menunjukkan bahwa ada perbedaan yang sangat signifikan pada taraf 99\% tingkat empati antara sebelum mendapatkan perlakuan CBT (Cognitif Behavior Therapy) dengan sesudah mendapatkan perlakuan CBT. Setelah mendapatkan perlakuan CBT tingkat empati lebih tinggi dibandingkan sebelum mendapatkan perlakuan CBT. Berdasarkan nilai partial eta squared ( $c^{2}$ ) diketahui besarnya sumbangan CBT terhadap empati adalah 30,8 \%.

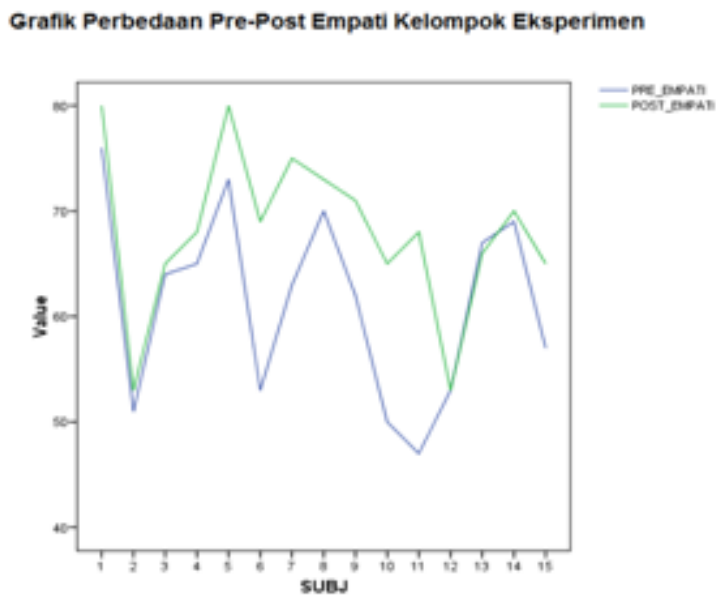

Gambar 3. Grafik Perbedaan Pretest -Posttest Skor Empati Kelompok Eksperimen
Keefektifan CBT tersebut didukung oleh beberapa penelitian yang sudah pernah dilakukan sebelumnya. Hasil penelitian Baqi (2009) menunjukkan bahwa secara akuntabilita CBGT (Cognitif Behavior Group Therapy) berhasil membantu 5 siswa yang menjadi subjek kelompok kontrol dalam meningkatkan kemampuan mengelola marah sehingga intensitas marah dapat diturunkan. Sedangkan hasil penelitian Susiatmika, Keliat, Wardani (2011) menunjukkan penurunan gejala perilaku kekerasan lebih besar pada klien yang mendapatkan CBT dan REBT daripada yang tidak mendapatkan CBT dan REBT (nilai $\mathrm{p}$ $<0,05)$. Kemampuan kognitif, afektif dan perilaku klien yang mendapatkan CBT dan REBT meningkat secara bermakna (nilai $\mathrm{p}<0,05$ ). CBT dan REBT direkomendasikan sebagai terapi keperawatan pada klien perilaku kekerasan danhalusinasi.

Hal ini menunjukkan bahwa CBT secara efektif memberikan dampak dalam menurunkan perilaku agresif dan meningkatkan empati. Semua from dalam cognitive behavior therapy menurut Beck's (2011), treatment berdasar cognitive formulation (formulasi kognitif), keyakinan dan perilaku. Treatment juga berdasar pada konseptualisasi, pemahaman, diri klien terkait keyakinan, dan perilaku yang akan diubah. Terapis mendorong, mengajarkan klien untuk memberikan alternatif alur pikir atau alasan lain pada klien dalam menyelesaikan permasalahan, memodifikasi dalam berfikir dan akan merubah keyakinannya yang diikuti perubahan emosi yang dirasakan dan perilaku yang berubah.

Proses kognitif terkait adanya dysfunctional thinking yang memunculkan perasaan negative dan perilaku yang tidak adaptif yang dapat menyebabkan gangguan psikologis. Ketika individu kembali mempelajari pikirannya untuk lebih realistis dan jalan keluar yang lebih adaptif, mereka akan merasakan pengalaman peningkatan yang jauh lebih baik terkait perasaan dan tingkahlakunya yang lebih adaptif (Beck’s, 
2011).

Meichenbaum (1989), menyatakan bahwa modifikasi perilaku kognitif adalah sebuah pernyataan diri yang akan mempengaruhi tingkah laku seseorang sebagaimana pernyataan diberikan oleh orang lain dengan cara mengenali cara berpikir, merasa bertindak, serta bagaimana akibatnya terhadap orang lain, dengan cara mengembangkan keterampilan kognisi, emosi dan perubahan perilaku agar masalah kognisi dan perilaku tidak muncul kembali. Froggatt (2006), semua terapi tentang kognitif yang berkembang selama ini pada dasarnya merupakan suatu pendapat bahwa perasaan dan sikap manusia sangat dipengaruhi oleh pola pikir mereka (kognitif). Dengan mempengaruhi pola pikir (kognitif) melalui metode Cogintive and Behaviour dapat merubah gangguan emosi dan sikap manusia.

Penelitian yang telah dilakukan ini tidak lepas dari berbagai kelemahan. Kelemahan yang perlu ditekankan dalam penelitian ini adalah dalam proses pemberian perlakuan dalam penelitian ini yang terlalu cepat yaitu 6 kali pertemuan, sehingga nilai-nilai yang terkandung dalam CBT belum benar-benar dipahami dan diterapkan oleh remaja. Kelemahan lain dalam penelitian ini adalah proses pemberian perlakuan tidak dapat sepenuhnya dikontrol dengan ketat, karena perlakuan dilakukan di dalam kelas di mana juga ada kelas-kelas lain yang juga sedang belajar. Akibatnya anak-anak yang mengikuti proses perlakuan terkadang mudah beralih perhatian.

\section{SIMPULAN}

CBT sebagai stimulasi berperan dalam menurunkan perilaku agresif dan meningkatkan empati pada remaja yang menjadi siswa di sekolah dengan fasilitas terbatas dan bukan sekolah favorit. Tingkat agresifitas setelah mendapatkan CBT lebih rendah dibandingkan tingkat agresifitas sebelum mendapatkan CBT.
Berdasarkan nilai partial eta squared ( $c^{2}$ ) diketahui besarnya sumbangan CBT dalam menurunkan perilaku agresif pada remaja adalah 23,7 \%. Sedangkan tingkat empati setelah mendapatkan CBT lebih tinggi dibandingkan tingkat empati sebelum mendapatkan CBT. Berdasarkan nilai partial eta squared ( ç$^{2}$ ) diketahui besarnya sumbangan CBT dalam meningkatkan empati pada remaja adalah 30,8 \%. Mengingat bahwa CBT sebagai stimulasi memiliki kontribusi dalam menurunkan perilaku agresif dan meningkatkan empati pada remaja, maka guru diharapkan menggunakan CBT secara berkelanjutan untuk menurunkan perilaku agresif dan meningkatkan empati. Penelitian selanjutnya diharapkan di dalam proses pemberian suatu perlakuan dilakukan dalam kurun waktu yang lebih lama, secara berkelanjutan dan di seluruh tingkatan usia. Selain itu, penelitian selanjutnya juga diharapkan untuk mempertimbangkan faktor lain yang dapat mempengaruhi perilaku agresif dan empati misalnya kondisi emosi, faktor sosial lain seperti keluarga, televisi, teman sebaya.

\section{DAFTAR PUSTAKA}

Baron, RA \& Byrne, D.2005. Psikologi Sosial. Jakarta : Erlangga.

Baqi, Saifudin. 2008. Pengaruh CognitiveBehavior Group Therapy Terhadap Peningkatan Anger Management . Jurnal. Jurusan Psikologi, Fakultas Pendidikan Psikologi, Universitas Negeri Malang

Beck, Judit. 2011. Cognitive Behavior Therapy Basic and Beyond. Second Edition. The Guilford Press. New York. London.

Borba, M. 2001. Building moral intelligence. San Fransisco : Josey-Bass. 
Brotoseno, I. 2008. Stop bullying. blog.imanbrotoseno.com/?p=318. Diunduh pada tanggal 30 Juli 2008.

Cook, T.D \& Campbell, D.T. 1979. Quasiexperimentation design and analysis issues for field settings. USA: Houghton Mifflin Company.

Farida,U. 2007.Hubungan Tipe Kepribadian Ekstrovert dan introvert dengan Perilaku agresif pada Remaja. Skripsi. Malang: fakultas Psikologi Universitas Islam Negeri Malang.

Froggatt, W. 2005. A Brief Introduction To Rational Emotive Behaviour Therapy (3. edition), New Zealand Centre for Cognitive Behaviour Therapy.

Gamayanti, I.L. 2003. Si pembuat onar : perilaku anak usia dini kasus dan pemecahannya. Yogyakarta: Penerbit Kanisius.
Krahe, B. 2001. Perilaku Agresif. Terjemahan.Yogyakarta : Pustaka Pelajar.

Meichenbaum, D. H. 1989 . Cognitive Behavior Modification: Effective Interventions With Adults, Children, and Adolescents. Seminar Presented Though The Institute For The Advancement of Human Behavior, Atlanta, GA.

Susiatmika., Keliat., Wardani. 2011. Efektivitas Cognitive Behavior Therapy Dan Rational Emotive Behavior Therapy Terhadap Gejala Dan Kemampuan Mengontrol Emosi Pada Klien Perilaku Kekerasan. Jurnal Penelitian. Keilmuan Keperawatan Jiwa Fakultas Ilmu Keperawatan Universitas Indonesia, Kampus UI Depok, Jakarta 10430, Indonesia. 
